\title{
The Research Review on PEAD and PFRD Share Price Drift Phenomenon
}

\author{
YANG Xiaolin ${ }^{1, a}$ \\ ${ }^{1}$ Business School,Beijing Normal University,BeiJing 100875 China \\ ayangxiaolin038@163.com
}

Keywords: Earnings announcement; PEAD; forecast revision; PFRD

\begin{abstract}
The share price drift phenomenon is an important abnormality frequently occurred in the stock market. It is caused by some events that are related to share price or yield rate. In this thesis, the author summarized and systemized the research literatures of share price drift phenomenon from earnings announcement and forecast revision. Each topic could be divided into two parts. In the first part, the author studied whether share price drift phenomenon exists under the influences of events. The other part is the cause of share price drift phenomenon. In the process of systemizing the literatures, PEAD and PFRD can be found out, but the causes for these two phenomena may not be identical. PEDA is explained from the perspectives of asymmetric information and risk costs, while PFRD is elaborated from the perspectives of insufficient investor response and asymmetric information.
\end{abstract}

\section{Post-earnings Announcement Drift(PEAD)}

PEAD refers to post-earnings announcement drift. To be specific, after earnings announcement of share price, if unexpected earnings are positive, there are positive abnormal returns. Share price will continue upward drift; on the contrary, if unexpected earnings are negative, there are negative abnormal returns and share price will continue downward drift(L. Liang, 2003).

\subsection{Studies on the Existence of PEAD}

The studies of predecessors on share price drift phenomenon are mainly concentrated on PEAD - the studies on PEAD. The studies of overseas scholars range from the existence of PEAD to causes of such a phenomenon. PEAD was firstly discovered by Ball and Brown(1968) in their study. since then, researchers in various countries have studied it in detail and have found out the evidence to prove the existence of PEAD in multiple stock markets around the world. Bernard \& Thomas(1989, 1990) and Kim et al(2003) found that there is PEAD in the American stock market. Hew et al(1996), Truong(2010) and Jihoon \& Byoung-Hyun(2017) observed the existence of PEAD in the British stock market, Zelanian stock market and Korean stock market, respectively. Meanwhile, Carlos et al(2005) also found out such a similar anomaly in Spanish stock market. Chudek et al(2011) discovered such a phenomenon in Canadian stock market. Truong(2011) utilized data research from 1994 to 2009 in Chinese stock market to find out PEAD in this market. In addition, Chinese researchers Li Sheng(2006) and Lu Ting(2012) also proved the existence of PEAD in Chinese stock market.

\subsection{The Studies on the Causes of PEAD}

Since PEAD is so ubiquitous in the global market, but what kinds of factors have caused the occurrence of such a phenomenon? Based on the experience of predecessors, causes are attributed to two aspects: PEAD is explained from the perspectives of information disclosure and investor behaviors and the perspective of risks or costs.

As everyone knows, Fama \& French proposed the effective market theory. If the market is effective, after issuing earnings announcement, investors have already gained new information and share price will make a response to information rapidly, thus there is no share price drift phenomenon. However, PEAD is ubiquitous in the global market, showing that the market is not the perfect market. Therefore, some scholars have studied PEAD from the perspective of information 
disclosure and investor behavior. For example, Efendi et al(2014) found that after 2009, the implementation of XBRL in the American stock market made the information more effective, so PEAD was slightly reduced. George(2014) found that anchoring prejudice will cause the generation of PEAD. Jihoon and Byoung-Hyun(2017) indicated that the anchoring prejudice in Korean stock market is attributed to the generation of PEAD. When share price level gets close to the peak and realizes the positive earnings, investors have no sufficient response, because they think such information has already been brought in price. Similarly, they underestimate the influences of current earnings on the future earnings. Similar to this hypothesis, they found that in good new share, as rising share price, drift is more obvious. Yu Lisheng(2006) found that information quality is the important cause for generation and continuity of PEAD. Lu Ting(2012) took advantage of the study in behavioral finance. The pricing biased error caused by investor emotion has correlation between stocks, so as to constitute the systematic pricing biased error in the market. By using A-share trading data from June 2003 to June 2009 in China, it could be found that the above-mentioned PEAD in Chinese stock market may be attributed to systematic pricing biased error.

Other scholars have explained PEAD from the perspective of risks or costs. Choi(2001) noted that for good news, the stock with the higher turnover after controlling price changes and enterprise characteristics, there is the larger share price drift. For bad news, there is no systematic correlation between turnover and share price drift. The author thinks that this may be attributed to the short-sale contraints. Kim(2003) added risk factor on the basis of three-factor model of Fama\& French to construct the four-factor model and utilized data in 1984-1999 to prove that the risk factor can explain PEAD. Also, he indicated that the reason why the anomaly hasn't been explained before is that model selection has an error. $\mathrm{Ke}(2005)$ found that no matter for direct or indirect trading costs, both of them will reduce institutional investors' positivity in using PEAD. Sadka(2006) indicated that PEAD in stock market may undertake the corresponding liquidity risk. Moreover, stock trading costs of insufficient liquidity are higher. Market influence costs also will be higher. Truong(2010, 2011) showed that scale of PEAD will be increased with the increase of risk arbitrage. By virtue of data in 2003-2010, Altınkılıç et al(2016) drew a conclusion that in the high-frequency trading era, stock yield drift phenomenon will exist in some high-cost trading. Kong Dongmin and Ke Ruihao(2007) firstly studied the driving cause of PEAD in Chinese stock market, finding that under the circumstance of different investors' possession, PEAD in Chinese stock market embody the unsymmetrical behavior characteristics, because of short-sale constraints in Chinese stock market.

\section{Post-forecast Revision Drift(PFRD)}

Securities analysts play an important role in the securities market. They are considered as intermediary agents to help investors to provide the necessary reference suggestion and reduce investment earnings when they make an investment decision, so as to protect investors from suffering losses. According to statistical data in the Development Report of Chinese Securities Business, it showed that natural investor accounts in Chinese securities market accounted for more than $99 \%$, but only minorities of them belonged to the institutional investor accounts, indicating that majorities of participants in Chinese securities market are individual investors. Securities analysts depend on their professional knowledge and information collection advantages to give the corresponding securities grading and earnings forecast. In theory, as investors, according to their own judgment, they can gain the corresponding abnormal returns relying on information provided by analysts.

PFRD refers to post-forecast revision. It means that securities analysts will regularly issue the earnings per share and previous forecast revision, including information of stock price and expected earning changes. Existing studies find that in post-forecast revision, long-term stock earnings often change with the revision. Such a phenomenon is called as PFRD.

\subsection{Studies on the Existence of PFRD}

Some scholars studied PFRD. Givoly \& Lakonishok(1980) found out the existence of PFRD for the first time. In PFRD, there is a share price drift phenomenon. Afterwards, Stickel(1991), Chan, 
Jegadeesh \& Lakonishok(1996), Gleaso \& Lee(2003) and Yuan Zhang(2008) also found out the similar share price drift phenomenon. PFRD still generates a significant influence on share price after a long time. That is to say, share price has the significant drift phenomenon on PFRD, indicating that the market doesn't absorb information contained in PFRD in time. Chinese researcher Ding Fangfei(2016) also utilized the event research method and considered single A-share forecast data in 2006-2013 as a sample to analyze influences of forecast revision on share price in different window periods, finding that forecast revision has the share price drift phenomenon that is similar to earnings announcement. Moreover, forecast revision with abundant information is more obvious.

\subsection{The Studies on the Causes of PFRD}

By systemizing literatures, the causes of PFRD can be found out. Researchers explained it from the perspectives of investors' insufficient response, analyst tracking and asymmetric information.

Givoly and Lakonishok (1980), Stickel (1991), Chan, Jegadeesh, Lakonishok(1996), Gleason and Lee (2003), Zhang (2006a), Hui and Yeung (2013) attributed PFRD as the investors' insufficient response after study. Based on it, Chen et al(2015) used data in 1983-2013 to find that there is the important association between analysts' insufficient response and PFRD.

Gleason (2003) observed that PFRD is related to analyst tracking. Hou et al(2016) utilized data in 1998-2009 in Canadian stock market to find that new information of forecast revision won't be timely and effectively responded to the share price. PFRD has the negative correlation with analyst tracking. As introducing the stricter information disclosure criteria, the market will be more efficient.

\section{Summary}

Based on the above-mentioned literatures, it can be observed that PFRD and PEAD have a close relation. PFRD studied yield drift from the relative perspective, while PEAD studied share price drift from the absolute perspective. In addition, it can be found that no matter in domestic or overseas, PEAD is a ubiquitous market anomaly, which is widely proven by researchers. At the same time, the studies on the causes are relatively transparent, but there are a few studies on PFRD and it is just remained in the existence of such a phenomenon. The causes of generation are relatively insufficient. In the future, researchers can study share price drift from the perspective of forecast revision. First of all, researchers can study whether there is the share price drift phenomenon. For example, in different securities markets, whether such a phenomenon will have a difference in developed market and developing market. Secondly, researchers should further study causes of PFRD under the enlightenment of studying PEAD, such as asymmetric information, risk costs, and investors' insufficient response.

\section{References}

[1]. Ball R, Brown P. An Empirical Evaluation of Accounting Income Numbers[J]. Journal of Accounting Research, 1968, 6(2):159-178.

[2]. Ball R, Brown P. An Empirical Evaluation of Accounting Income Numbers[J]. Journal of Accounting Research, 1968, 6(2):159-178.

[3]. Bartov E, Radhakrishnan S, Krinsky I. Investor Sophistication and Patterns in Stock Returns after Earnings Announcements [J]. Accounting Review, 2000, 75(1):43-63.

[4]. Bernard V L, Thomas J K. Evidence that stock prices do not fully reflect the implications of current earnings for future earnings $\hat{\zeta}[J]$. Journal of Accounting \& Economics, 1990, 13(4):305-340.

[5]. Bernard V L, Thomas J K. Post-Earnings-Announcement Drift: Delayed Price Response or Risk Premium?[J]. Journal of Accounting Research, 1989, 27(27):1-36. 
[6]. Chan L K C, Jegadeesh N, Lakonishok J. Momentum Strategies[J]. Journal of Finance, 1996, 51(5):1681-1713.

[7]. Chen P C, Narayanamoorthy G S, Sougiannis T, et al. Analyst Underreaction and the Post-Forecast Revision Drift[J]. Social Science Electronic Publishing, 2015.

[8]. Choi W, Kim J W. Underreaction, Trading Volume and Post earnings announcement drift[J]. Ssrn Electronic Journal, 2001, 4(4):481 - 486.

[9]. Chordia T, GAltınkılıç et al.l A, Sadka G, et al. Liquidity and the Post-Earnings-Announcement Drift[J]. Financial Analysts Journal, 2009, 65(4):18-32.

[10]. Chudek M, Truong C, Veeraraghavan M. Is trading on earnings surprises a profitable strategy? Canadian evidence[J]. Journal of International Financial Markets Institutions \& Money, 2011, 21(5):832-850..

[11]. Denis Hew, Len Skerratt, Norman Strong, et al. Post-earnings-announcement Drift: Some Preliminary Evidence for the UK[J]. Accounting \& Business Research, 1996, 26(4):283-293.

[12]. Efendi J, Jin D P, Smith L M. Do XBRL filings enhance informational efficiency? Early evidence from post-earnings announcement drift[J]. Journal of Business Research, 2014, 67(6):1099-1105.

[13]. Fang L H, Yasuda A. Are Stars'Opinions Worth More? The Relation between Analyst Reputation and Recommendation Values[J]. Journal of Financial Services Research, 2011.

[14]. Forner C, Sanabria S, Marhuenda J. Post-earnings announcement drift: Spanish evidence[J]. Spanish Economic Review, 2009, 11(3):207-241.

[15]. George T J, Hwang C Y, Li Y. Anchoring, the 52-Week High and Post Earnings Announcement Drift[J]. Social Science Electronic Publishing, 2014.

[16]. Givoly, D. and Lakonishok . Financial analysts' forecasts of earnings [J]. Journal of Banking \& Finance, 1980,4(3):701-737.

[17]. Gleason C A, Lee C M C. Analyst Forecast Revisions and Market Price Discovery[J]. Accounting Review, 2003, 78(1):193-225.

[18]. Goh, Jeon, ByoungHyun. Post-earnings-announcement-drift and 52-week high: Evidence from Korea[J]. Pacific-Basin Finance Journal, 2017, 44.

[19]. Hou C T, Mcknight P, Weir C. Returns to buying upward revision and selling downward revision stocks: evidence from Canada[J]. Social Science Electronic Publishing, 2016, 42(11):1110-1124.

[20]. Hui K W, Yeung P E. Underreaction to Industry-Wide Earnings and the Post-Forecast Revision Drift[J]. Journal of Accounting Research, 2013, 51(4):701-737.

[21]. Ke B, Ramalingegowda S. Do institutional investors exploit the post-earnings announcement drift?[J]. Journal of Accounting \& Economics, 2005, 39(1):25-53.

[22]. Kim D, Kim M. A Multifactor Explanation of Post-Earnings Announcement Drift[J]. Journal of Financial \& Quantitative Analysis, 2003, 38(2):383-398.

[23]. Liang L. Post-Earnings Announcement Drift and Market Participants' Information Processing Biases[J]. Review of Accounting Studies, 2003, 8(2-3):321-345.

[24]. Sadka R. Momentum and post-earnings-announcement drift anomalies: The role of liquidity risk [J]. Social Science Electronic Publishing, 2006, 80(2):309-349.

[25]. Stickel S E. Common Stock Returns Surrounding Earnings Forecast Revisions: More 
Puzzling Evidence[J]. Accounting Review, 1991, 66(2):402-416.

[26]. Truong C. Post earnings announcement drift and the roles of drift-enhanced factors in New Zealand[J]. Pacific-Basin Finance Journal, 2010, 18(2):139-157.

[27]. Zhang Y. Analyst Responsiveness and the Post-Earnings-Announcement Drift[J]. Journal of Accounting \& Economics, 2008, 46(1):201-215.

[28]. Ding F.F, Liao Y, and Kong L. F. the Influence Study of Forecast Revision on Share Price[J], Communication of Finance and Accounting, 2016(27).

[29]. Kong D.M and Ke R.H. Who Drive the PEAD in Chinese Stock Market?[J] Finance Research, 2007(10a): 82-99.

[30]. Lu T. Systematic Pricing Biased Error: Price Drift Study after A-share Earnings Announcement in China[J], Finance Research, 2012(3): 82-99.

[31]. Yu L.S and Wang Y.Y, Information Uncertainty and PEAD—Experimental Evidence in Chinese Listed Companies[J], Management World, 2006(3): 40-49 